\title{
Konstruk Persempadanan Etnik dalam Pilihan raya: Kajian Kes Etnik Kadazandusun di Sabah
}

\author{
FADILAH BINTI SARBI \\ Unit Penyelidikan Etnografi dan Pembangunan, Fakulti Kemanusiaan, Seni dan Warisan, \\ Universiti Malaysia Sabah, Jln UMS, 88400 Kota Kinabalu
}

fadilasarbi@gmail.com

Abstrak Persempadanan memainkan peranan penting dalam perkembangan dunia, tanpa mengira jenis sempadan yang ada, sama ada pilihan raya negeri atau negara. Artikel ini akan membincangkan tentang konstruk persempadanan pilihan raya yang memfokuskan kepada persempadanan etnik mengikut pembahagian kawasan pilihan raya. Kajian telah dilakukan di negeri Sabah dengan membandingkan dua persempadanan pilihan raya yang telah dikeluarkan oleh Suruhanjaya Pilihan Raya Malaysia (SPR) iaitu pada tahun 1994 dan 2004. Kajian ini dilakukan bertujuan untuk melihat kedudukan kerusi atau sempadan pilihan raya, sama ada dilakukan berdasarkan kumpulan etnik atau sebaliknya. Data yang diguna pakai dalam kajian ini bersifat sekunder, iaitu data persempadanan pilihan raya yang dikeluarkan pada tahun 1994 dan 2004, data penduduk Sabah keseluruhannya berdasarkan daerah pentadbiran dan kumpulan etnik tahun 1990 dan 2000. Data-data yang digunakan dalam kajian adalah daripada SPR, Jabatan Perangkaan dan Laporan Rancangan Malaysia ke-8. Kajian telah menggunakan aplikasi GIS (Sistem Maklumat Geografi) sebagai alat bantu dalam penganalisisan data ruangan yang berkaitan. Pertambahan penduduk merupakan indikator jelas menyebabkan pertambahan kerusi pilihan raya secara keseluruhannya. Dapatan kajian yang dilakukan menunjukkan secara jelas bahawa etnik memainkan peranan yang penting dalam pembentukan sempadan yang dilakukan biarpun tidak dinyatakan secara jelas. Kertas kerja ini memberi fokus kepada etnik majoriti di negeri Sabah, iaitu etnik Kadazandusun dalam persempadanan etnik di negeri ini. Jelas melalui kajian ini, penerapan konsep racial gerrymandering iaitu memberi kelebihan kepada sesuatu etnik bagi konstruk persempadanan telah diaplikasikan di Malaysia.

Kata kunci: Persempadanan pilihan raya, etnik, GIS, Sabah, Kadazandusun. 
Abstract Boundary is very important for world development, regardless of the levels of election, namely the federal or state election. This article discusses the delimitation of electoral constructs which focuses on ethnic boundaries in accordance with the division of constitutions. Studies have been conducted in the state of Sabah by comparing two electoral boundaries that have been delineated by the Election Commission of Malaysia in 1994 and 2004. This study was conducted to determine whether the position of the seats or electoral boundaries was carried out based on ethnicity or otherwise. Data used in this research is secondary data, namely data delimitation of election issued in 1994 and 2004, population data by administrative districts of Sabah and ethnic groups in 1990 and 2000. The data used in the study are from the Election Commission (EC) Malaysia, Department of Statistics and Report of the 8th Malaysia Plan. GIS applications as a tool were used in analysing data. The result clearly showed that ethnicity played an important role in the formation of boundaries although not explicity stated by the Electrocal Commission. This study focused on the majority ethnic group in the state which is the Kadazandusun. To conclude, the application of the concept of racial gerrymandering in constructing electoral boundaries has been applied in Malaysia.

Keywords: Electoral boundaries, ethnic, GIS, Sabah, Kadazandusun.

\section{PENGENALAN}

Kawasan merupakan subjek utama dalam terma geografi. Ia cukup sinonim dengan permukaan, identiti dan bentuk fizikal yang biasanya akan berkaitan dengan kedaulatan negara, ketinggian budaya dan komitmen mempertahankan yang didasari dengan persempadanan. Realitinya, persempadanan adalah kawasan yang berasaskan garisan dan boleh berubah, akan tetapi meliputi banyak interaksi dan persefahaman seperti pendekatan pembangunan, agenda kerajaan, perkembangan politik serta faktor luaran seperti globalisasi. Persempadanan biasanya akan menghasilkan ruangan yang akan menjadi medan pertembungan kuasa dan ideologi parti politik yang bertanding. Biasanya, pembikinan sempadan adalah bergantung kepada beberapa faktor seperti lokaliti sesuatu kawasan, namun persempadanan 
politik adalah lebih sensitif untuk diperkatakan kerana secara langsung akan berkait dengan kuasa, identiti sosial, elemen keruangan, etnik, hegemoni, pertimbangan profesional, kontroversi sains, sejarah, budaya, hak asasi manusia, migrasi dan politik dalaman (Paasi, 2002; Norris \& Harring, 1980; Kasperson, 1973).

Geografi politik adalah kajian tentang dimensi ruangan dan pelbagai dimensi lain dalam politik. Sarjana dalam bidang geografi politik mengkaji pelbagai dimensi geografi dan politik yang meliputi aspek persempadanan, negara, negeri, tempatan atau lokaliti, pembangunan, organisasi antarabangsa, diplomasi dan sebagainya. Pelbagai kriteria yang diambil kira dalam penentuan persempadanan semula di mana-mana negara di seluruh dunia seperti pengundi, pola petempatan, densiti penduduk, komposisi penduduk, bentuk muka bumi dan ekonomi (Kasperson, 1973, Agnew \& Corbridge, 1995, Glassner, 1995, Paasi, 2002 dan Blacksell, 2006). Dalam penyelidikan ini, aspek yang disentuh adalah berkaitan dengan persempadanan etnik dalam pilihan raya umum di Sabah. SPR merupakan agensi yang bertanggungjawab terhadap perubahan sempadan pilihan raya yang berlaku di negeri ini.

Tulisan ini akan mengupas persoalan utama dalam pola persempadanan DUN Sabah, iaitu berkaitan dengan perubahan ruangan sempadan politik berdasarkan, etnik Kadazandusun. Perubahan persempadanan dianalisis, iaitu persempadanan dan data yang telah digunakan pada tahun 1994 dan 2004. Pemilihan persempadanan pilihan raya tahun 1994 dan 2004 dilakukan kerana kedua-dua pilihan raya berkenaan mengalami perubahan persempadanan dan juga data sokongan lain seperti data penduduk, sosioekonomi dan taburan etnik diperoleh secara lengkap berbanding tahun-tahun sebelumnya. Secara keseluruhannya, kajian yang dijalankan akan menggunakan aplikasi teknologi, iaitu penggunaan GIS dalam penyimpanan, memanipulasi dan menganalisis data yang berkaitan melalui analisis ruangan melalui teknik tindan lapis. Setiap lapisan ruangan yang ada disertakan dengan maklumat dan data berkaitan etnik. Penerapan teknologi terkini ini dapat membantu dalam bidang penyelidikan dan pelbagai bidang kajian untuk perkongsian maklumat yang ada dan sebagai pemudah cara pemahaman berkaitan data ruangan setelah analisis dilakukan. 


\section{PERSEMPADANAN GEOGRAFI POLITIK}

Ahli geografi sering menyatakan bahawa persempadanan politik lahir daripada idea tradisi mereka yang melibatkan garisan atas peta serta fungsi persempadanan (institusi, simbol dan sumber) yang berkembang dengan pantas pada tahun 1990-an. Pada dasarnya, terdapat lima elemen yang memberi impak kepada pembikinan persempadanan iaitu sosioekonomi, globalisasi, situasi 'postmodern', teknologi dan ekopolitik (O'Tuathail \& Dalby, 1998 dan Paasi, 2002). Jadual 1 menerangkan secara terperinci berkaitan dengan elemen yang terlibat dalam persempadanan politik.

Jadual 1 Elemen-elemen yang diambil kira dalam pembentukan persempadanan politik

\begin{tabular}{ll}
\hline Elemen & \multicolumn{1}{c}{ Perincian } \\
\hline Sosioekonomi & Berkaitan dengan peraliran ekonomi dan kewangan \\
Globalisasi & $\begin{array}{l}\text { Perubahan secara drastik atau besar berkaitan dengan ekonomi, } \\
\text { budaya dan skala pergerakan }\end{array}$ \\
Situasi postmordern & $\begin{array}{l}\text { Perubahan yang melibatkan sosial manusia dengan identiti } \\
\text { semula jadi, pengetahuan dan keagamaan }\end{array}$ \\
Teknologi & $\begin{array}{l}\text { Perkembangan informasi baharu berkaitan dengan peralatan, } \\
\text { perkakasan dan ruangan siber }\end{array}$ \\
Ekopolitik & $\begin{array}{l}\text { Permasalahan berkaitan persekitaran hasil daripada impak } \\
\text { negatif kemajuan seperti hujan asid dan pencemaran }\end{array}$ \\
\hline
\end{tabular}

Sumber: Paasi, 2002

Sarjana geografi politik mengklasifikasikan persempadanan yang dihasilkan daripada idea geografi adalah hasil daripada kartografi, imaginasi, nilai sosial dan kuasa politik. Gabungan ini akan menghasilkan sempadan yang akan menjadi sejarah dan membantu dalam pembinaan kuasa dan pembangunan (Boots, 2000). Pembikinan persempadanan telah mendapat titik sentuhan teknologi sejak 1950 lagi. Sementara komputer yang mempunyai elemen kartografi diguna pakai dalam penghasilan peta yang bersempadan dikehendaki. Sehingga awal tahun 1980, satu perisian diwujudkan dan menjadi pemudah cara iaitu Sistem Maklumat Ruangan yang berfungsi sebagai alat kartografi tetapi juga untuk menganalisis serta memanipulasi data secara terus (Batty,1995). 


\section{PERSEMPADANAN PILIHAN RAYA (POLITIK) DI MALAYSIA}

Proses yang berkaitan dengan pilihan raya di Malaysia akan dikendalikan oleh SPR. Dalam penghasilan persempadanan pilihan raya di Malaysia, satu kajian biasanya akan dilakukan dan mengambil masa tidak kurang daripada lapan tahun dan hendaklah diselesaikan tidak melebih dua tahun dari tarikh kajian dimulakan. Kajian biasanya akan dilakukan bersama di antara SPR, Jabatan Ukur dan Pemetaan Malaysia (JUPEM), Jabatan Statistik serta Pejabat Peguam Negara. Selepas kajian diselesaikan, satu syor akan dikemukakan kepada Perdana Menteri dan seterusnya notis akan dikeluarkan di akhbar-akhbar arus perdana selama sebulan untuk proses bantahan. Selepas itu, jawatan kuasa akan bermesyuarat dan membuat keputusan berkaitan keputusan akhir persempadanan semula dan akhirnya akan dibawa ke Parlimen untuk mendapat persetujuan daripada Ahli Parlimen, iaitu sekurang-kurangnya $2 / 3$ daripada ahli yang ada. Persempadanan semula akan dilakukan oleh pihak SPR disebabkan oleh faktor yang berikut;

1. Pertambahan jumlah penduduk.

2. Pertambahan jumlah daftar pemilih sekurang-kurangnya 22 peratus dari jumlah sebelumnya.

3. Pertumbuhan bandar atau pusat pentadbiran baharu akan menyebabkan pertambahan kawasan pengundian baharu dan pesat membangun seperti Wilayah Persekutuan Putrajaya.

4. Peluang peningkatan dan kemajuan kawasan dalam konteks memberi kesamarataan dalam pengagihan dan kemudahan kepada rakyat.

Terdapat juga klasifikasi kawasan untuk persempadanan yang terkandung dalam Bab 14 (Laporan Perubahan Persempadanan Tahun 1994) dan Bab 16 (Laporan Perubahan Persempadanan Tahun 2004) seperti yang berikut; 
Jadual 2 Klasifikasi pembahagian kawasan dan pengundi

\begin{tabular}{lcc}
\hline Pilihan raya & Pengundi Parlimen & Pengundi DUN \\
\hline $\begin{array}{l}\text { Bandar (Maju) } \\
\text { Keluasan: } 8 \mathrm{~km}<500 \mathrm{~km}\end{array}$ & $40,000 \mathrm{ke}$ atas & 15,000 ke atas \\
$\begin{array}{l}\text { Luar Bandar (Sedang dimajukan) } \\
\text { Keluasan: } 501 \mathrm{~km}-<1,500 \mathrm{~km}\end{array}$ & $30,000-39,999$ & $10,000-14,999$ \\
$\begin{array}{l}\text { Luar Bandar (Belum dimajukan) } \\
\text { Keluasan: }>1,500 \mathrm{~km}\end{array}$ & Kurang 30,000 & Kurang 10,000 \\
\hline
\end{tabular}

Sumber: Suruhanjaya Pilihan Raya Malaysia

\section{Persempadanan Berasaskan Etnik}

Persempadanan politik biasanya melibatkan banyak unsur seperti yang telah dinyatakan sebelum ini. Namun, unsur etnik sememangnya memberi pangaruh yang agak kuat dalam menentukan persempadanan yang ada. Biarpun tidak dinyatakan secara sepesifik tentang pengaruh etnik, terdapat satu konsep yang sangat sinonim dengan persempadanan, iaitu gerrymandering yang menyatakan secara terus bahawa etnik merupakan salah satu pertimbangan yang perlu diambil kira. Konsep gerrymandering diperkenalkan oleh Massachusetts Govener Ellbridge Gerry pada tahun 1812 di Amerika Syarikat (Glassner, 1995). Konsep ini adalah satu kaedah mudah untuk mendapatkan sempadan pilihan raya dengan cara pemanipulasian sempadan bagi kepentingan semua pihak. Terdapat tiga perwakilan dalam konsep ini, iaitu Partisan Gerrymandering, Incumbent Protection Gerrymandering dan Racial Gerrymandering (Noris \& Haring, 1980).

Persempadanan berasaskan etnik jelas bermula daripada racial gerrymandering yang bermatlamat untuk memberi perlindungan dan hak sama rata kepada semua etnik dalam penentuan persempadanan. Persempadanan berasaskan etnik ini juga adalah untuk memberi kuasa yang adil kepada semua di samping menjadi salah satu langkah untuk mengelak pengasingan kuasa kaum minoriti yang ada bagi meningkatkan kualiti hidup (Pandley, 2007). Pengaplikasiannya di Amerika Syarikat telah termaktub dalam Voting Right Act (VRA) yang pada asalnya bertujuan untuk 
melindungi hak dan kepentingan etnik minoriti African-American pada tahun 1965, dan seterusnya dipanjangkan kepada etnik Hispanic pada tahun 1982 (Forest, 2007). Terdapat dua seksyen yang secara jelas melindungi hak etnik dalam VRA seperti yang berikut;

Seksyen 2: Pelukisan sempadan perlu mengambil kira faktor majoriti dan minoriti rakyat yang ada.

Seksyen 5: Persempadanan etnik ini adalah dilindungi selagi belum ada persempadanan semula dan hanya boleh diubah jika mendapat persetujuan daripada Jabatan Kehakiman dan mahkamah daerah asal.

\section{Persempadanan Dewan Undangan Negeri Sabah}

Sabah mencapai kemerdekaan melalui pembentukan gagasan persekutuan Malaysia pada 16 September 1963 bersama-sama Sarawak, Singapura dan Tanah Melayu. Pada fasa pra mencapai kemerdekaan, tercetus konfrontasi dari Filipina yang menganggap Sabah yang dikenali sebagai Borneo Utara merupakan milik Kerajaan Sulu (Andaya \& Andaya, 2001). Pemberontakan singkat juga berlaku di negara Brunei Darussalam yang diketuai oleh Sheikh Azhari kerana baginya pemberian Sabah kepada Syarikat Berpiagam Borneo Utara oleh Sultan Brunei adalah tidak sah (Mohd. Ariff Bin Dato' Hj. Othman, 1988) serta bantahan daripada Indonesia (Andaya \& Andaya, 2001). Namun, rakyat Sabah telah bersetuju setelah pungutan suara dilakukan yang dikenali sebagai Suruhanjaya Cobbold (Hooker, 2000). Secara keseluruhannya, Sabah telah menjalani 12 kali pilihan raya dan terdapat lima kali perubahan persempadanan pilihan raya yang memberi impak langsung kepada pertambahan jumlah kerusi yang dipertandingkan. Sememangnya perubahan sempadan di negeri Sabah mengambil kira pelbagai faktor termasuk kepelbagaian etnik di bawah satu parti yang menjadi identiti unik (Joisin Romut, 2004). 
Jadual 3 Jumlah kerusi yang dipertandingkan pada Pilihan raya Dewan Undangan Negeri Sabah, 1963-2008

\begin{tabular}{lcc}
\hline \multicolumn{1}{c}{ Pilihan raya } & Tahun & Jumlah Kerusi Dipertandingkan \\
\hline Pilihan raya 1 & 1963 & 16 \\
Pilihan raya 2 & 1967 & 32 \\
Pilihan raya 3 & 1971 & 32 \\
Pilihan raya 4 & 1976 & 48 \\
Pilihan raya 5 & 1981 & 48 \\
Pilihan raya 6 & 1985 & 48 \\
Pilihan raya 7 & 1986 & 48 \\
Pilihan raya 8 & 1990 & 48 \\
Pilihan raya 9 & 1994 & 48 \\
Pilihan raya 10 & 1999 & 48 \\
Pilihan raya 11 & 2004 & 60 \\
Pilihan raya 12 & 2008 & 60 \\
\hline Sumbr:
\end{tabular}

Sumber: www.dun.sabah.gov.my

Dalam senario persempadanan dan politik di Sabah, isu yang penting adalah berkisar tentang isu etnik, sejarah dan kebudayaan yang sememangnya bersifat pelbagai. Kategori pengundi di Sabah pula dibahagikan kepada empat yang telah ditentukan oleh SPR, iaitu Bumiputera Islam, Bumiputera Bukan Islam, Cina dan lain-lain. Namun, isu hangat berkaitan dengan persempadanan berlaku pada tahun 1999, apabila pertambahan yang mendadak berlaku bagi kerusi Bumiputera Islam Sabah (Joisin Romut, 1999).

\section{SISTEM MAKLUMAT GEOGRAFI DAN PERSEMPADANAN PILIHANRAYA}

Penggunaan aplikasi GIS dan komputer dalam persempadanan pilihan raya telah banyak diperdebatkan. Secara keseluruhannya, kajian berkaitan persempadanan politik dengan menggunakan komputer sebagai alat yang penting dalam menyimpan pelbagai data dan maklumat yang berkaitan telah dilakukan (Batty, 1980). Namun, sejak kebelakangan ini penggunaan sistem GIS sebagai alat yang penting dalam proses persempadanan yang dapat mempersembahkan maklumat secara keseluruhan, menyelesaikan masalah berkaitan ruangan dan konteks polisi juga dapat diguna pakai. Sebagai contoh di utara Amerika, komputer telah digunakan sejak 1950-an dalam konteks persempadanan ini. 
Penggunaan GIS mula diperkenalkan awal 1980-an dilihat dapat menyelesaikan masalah yang timbul. Malahan dengan adanya GIS, selain persempadanan berkaitan dengan pilihan raya, peta dapat dimanipulasi dan dianalisis secara terus. Sejak daripada itu, GIS digunakan dalam proses pembikinan persempadanan pilihan raya. Namun demikian, dalam penyelidikan ini penggunaan GIS adalah sebagai alat bantu utama untuk melihat perubahan persempadanan pilihan raya negeri Sabah tahun 2004 dengan membandingkan persempadanan tahun 1994. GIS membantu memperlihatkan ruangan yang terlibat dalam perubahan secara jelas. Selain itu, data yang terlibat, yang menggambarkan lokasi akan ditukar kepada bentuk ruangan yang dijelaskan melalui warna atau simbol tertentu (Miller, 2000). Secara keseluruhannya, aplikasi GIS sememangnya membantu dalam penyelidikan ini terutamanya pemaparan peta dan data ruangan yang jelas.

\section{METODOLOGI KAJIAN}

Asas penyelidikan ini adalah menggunakan analisis kuantitatif yang melibatkan pengiraan data nominal yang melibatkan pengelasan kategori. Selain itu, analisis ruangan menggunakan alat bantu, iaitu (Geographic Information System atau GIS) telah digunapakai. Sistem ini telah digunakan bagi tujuan mendefinisikan maklumat yang ada dalam bentuk fizikal (Bernhadsen, 2003). Analisis ruang tidak dapat lari daripada konsep geometri dan digabungkan dengan analisis statistik bagi mendapatkan keputusan yang lebih baik (Clark \& Hosking, 1986). Oleh yang demikian, persoalan kartografi berkaitan dengan persempadanan dapat diklasifikasikan dengan mudah, iaitu melalui pemaparan peta. Terdapat dua jenis pengelasan persempadanan, iaitu klasikal dan moden. Kajian ini telah menggunakan pengelasan moden iaitu terdapat hubung kait yang kuat dalam persempadanan dan bukannya sekadar pelakaran peta semata-mata.

Dalam kajian ini, analisis menggunakan GIS digunakan untuk mengesan reruang politik Sabah melalui penggunaan beberapa jenis data (rujuk Jadual 4). Dengan menggunakan data berkenaan, proses pemanipulasian data ruangan dengan menggunakan GIS yang menghasilkan data baru dalam bentuk kartografi (peta). Sistem Maklumat Geografi dapat 
mengklasifikasikan data dalam dua bentuk iaitu data atribut (data mentah dalam bentuk nombor dan perkataan) dan data ruangan (spatial) (Harring, 1992). Biasanya, proses pemanipulasian yang asas adalah menukarkan data atribut kepada data spatial bagi memudah cara pemahaman berkaitan dengan peta (rujuk Rajah 1). Selain itu, analisis tindan lapis (overlay) iaitu menggunakan lebih daripada satu data untuk menghasilkan satu peta yang baharu turut digunakan. Tujuan utama proses tindan lapis ini diguna pakai dalam kajian ini adalah untuk membuat perbandingan atau perubahan persempadanan politik. Sebelum analisis tindan-lapis dilakukan, biasanya proses kemasukan data atribut dan ruangan dilakukan pada setiap kawasan yang diwakili sebelum proses manipulasi data dilakukan (rujuk Rajah 2).
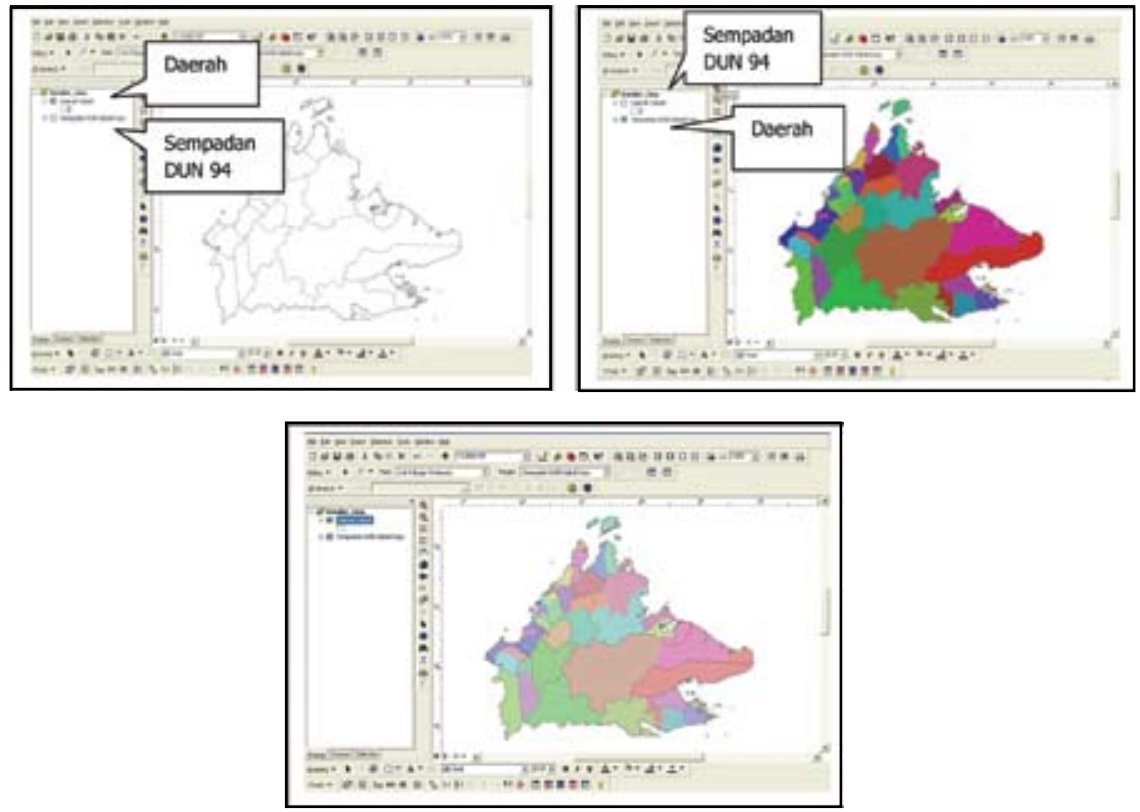

Rajah 1 Analisis tindan-lapis menggunakan aplikasi GIS 


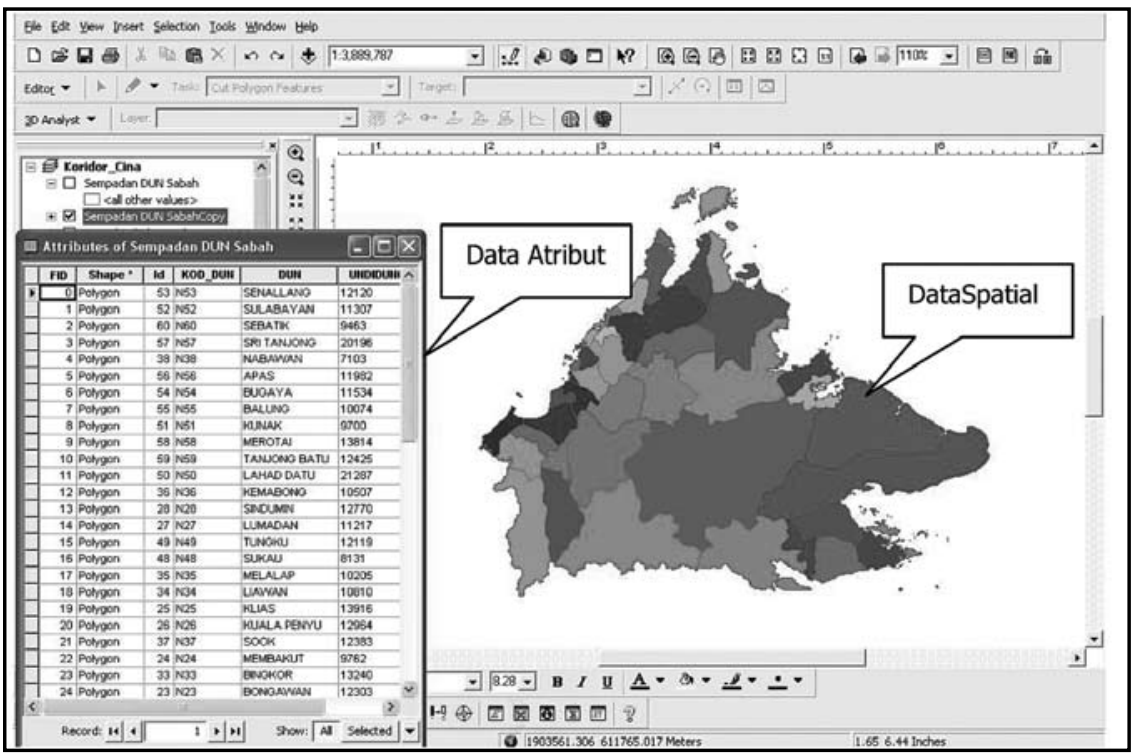

Rajah 2 Data atribut dan data ruangan aplikasi GIS

\section{Data-data yang diguna pakai}

Jadual 4 Data-data yang telah diguna pakai

\begin{tabular}{lcc}
\hline \multicolumn{1}{c}{ Jenis Data } & Spesifikasi & Tahun Dikeluarkan \\
\hline $\begin{array}{l}\text { Data persempadanan pilihan raya } \\
\text { (Suruhanjaya Pilihan raya Malaysia) }\end{array}$ & Persempadanan & 1993 dan 2003 \\
$\begin{array}{l}\text { Data taburan penduduk Sabah } \\
\text { secara keseluruhan (Jabatan Perangkaan }\end{array}$ & Demografi & 1991 dan 2000 \\
$\begin{array}{l}\text { Malaysia) } \\
\begin{array}{l}\text { Data taburan penduduk Sabah berdasarkan } \\
\text { kumpulan etnik } \\
\text { (Jabatan Perangkaan Malaysia) }\end{array}\end{array}$ & Demografi & 1991 dan 2000 \\
\hline
\end{tabular}

Sumber: Dipetik dan diubah suai daripada Laporan Persempadanan Pilihanraya Malaysia, Tahun 1993 \& 2003; dan Jabatan Perangkaan Malaysia. 


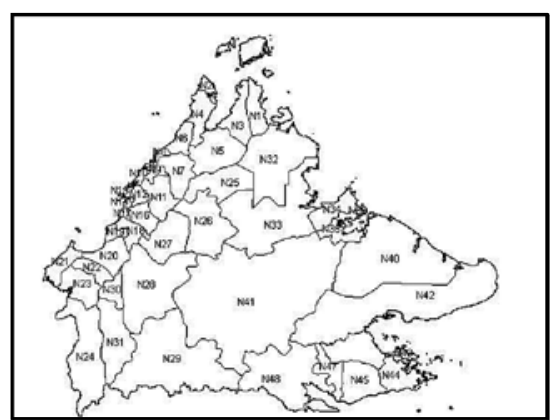

Rajah 3.1 Sempadan PR 1994

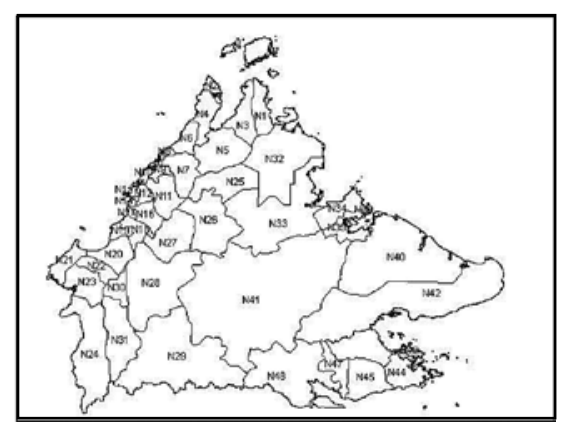

Rajah 3.2 Sempadan PR 2000

Sumber: Dipetik dan diubahsuai daripada Suruhanjaya Pilihan Raya Malaysia

Rajah 3 Data Persempadanan Pilihanraya Negeri Sabah

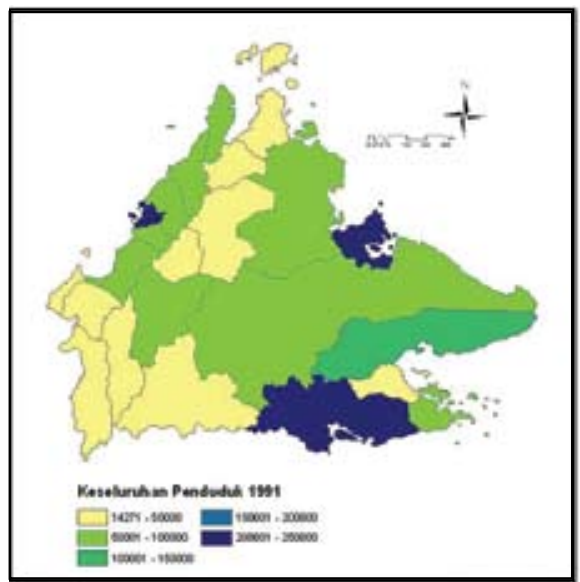

Rajah 4.1 Populasi Tahun 1991

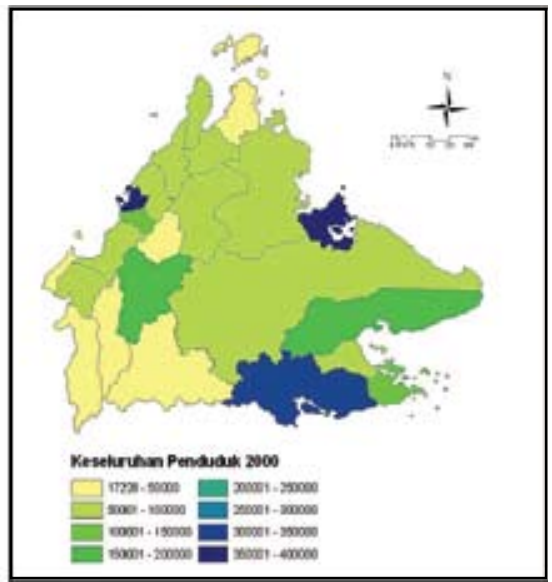

Rajah 4.2 Polulasi Tahun 2000

Sumber: Dipetik dan diubah suai daripada Jabatan Perangkaan Malaysia

Rajah 4 Taburan populasi penduduk negeri Sabah berdasarkan daerah pentadbiran 


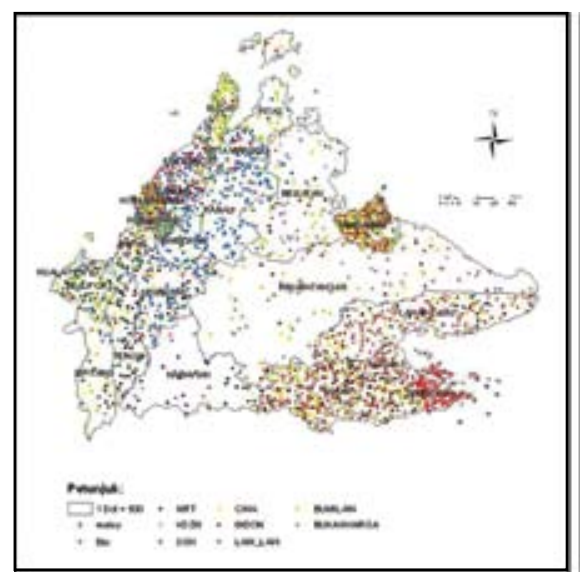

Rajah 5.1 Taburan Penduduk 1991

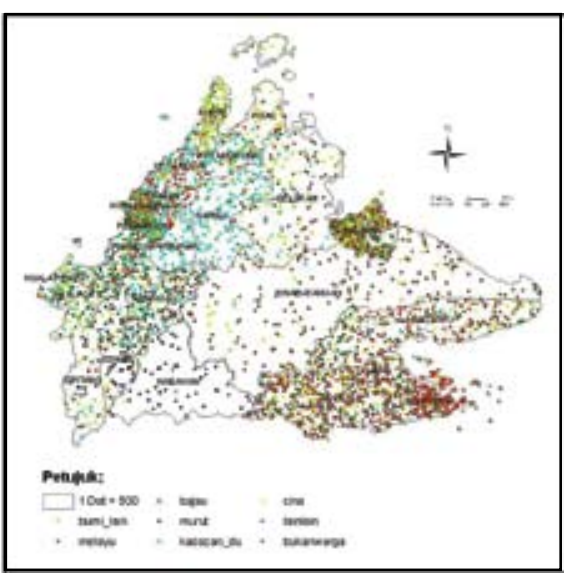

Rajah 5.2 Taburan Penduduk 2000

Sumber: Dipetik dan diubah suai daripada Jabatan Perangkaan Malaysia, 1991 \& 2000 dan Jabatan Tanah \& Ukur Sabah

Rajah 5 Data taburan penduduk sabah berdasarkan kumpulan etnik

\section{DAPATAN KAJIAN: KONSTRUK PERSEMPADANAN ETNIK}

Tidak ada dinyatakan dalam setiap laporan bahawa perubahan sempadan etnik merupakan salah satu faktor menyebabkan berlakunya perubahan persempadanan pilihan raya. Namun, kajian ini telah membuktikan bahawa faktor etnik merupakan salah satu faktor yang menyumbang kepada pertambahan persempadanan pilihan raya. Berbeza dengan Semenanjung Malaysia, Sabah merupakan negeri yang mempunyai pelbagai etnik. Namun dalam pembikinan persempadanan pilihan raya, SPR telah mengklasifikasikan kepada empat bangsa sahaja bagi mewakili kumpulan etnik di Sabah, iaitu Bumiputera Islam, Bumiputera Bukan Islam, Cina dan Lain-lain. Persempadanan berdasarkan kumpulan etnik ini sebenarnya mirip dengan apa yang dilakukan di Amerika Syarikat, iaitu Racial Gerrymandering yang sebenarnya melindungi sesuatu kaum yang ada melalui persempadanan pilihan raya. Empat etnik yang telah dipilih dalam kajian ini untuk mengesahkan bahawa adanya unsur etnik telah diguna pakai 
dalam setiap kali persempadanan pilihan raya dilakukan. Dalam kajian ini, etnik Kadazandusun telah memperlihatkan Racial Gerrymandering telah diaplikasikan di Malaysia, khususnya di Sabah.

\section{Etnik Kadazandusun}

Etnik terbesar di negeri Sabah ini berada di setiap daerah pentadbiran yang ada di negeri Sabah sama ada dalam jumlah majoriti atau minoriti di sesuatu kawasan. Namun etnik ini biasanya bertumpu di kawasankawasan pedalaman dan pantai barat negeri Sabah. Di sebelah pantai timur pula, komposisi penduduk daripada bangsa ini kurang dari segi jumlah keseluruhan yang dicatatkan. Mengikut jumlah penduduk yang dikeluarkan oleh Jabatan Perangkaan Malaysia pada tahun 1991 etnik ini dibahagikan kepada dua iaitu Dusun seramai 216,910 orang, manakala Kadazan seramai 104,888 orang dan jumlah keseluruhan dicatatkan adalah seramai 321,798 orang, iaitu melibatkan 18.5 peratus daripada keseluruhan penduduk Sabah. Pada tahun 2000 pula, setelah digabungkan menggunakan satu nama, etnik Kadazandusun jumlah keseluruhan penduduk yang dicatatkan adalah seramai 482,278 orang. 


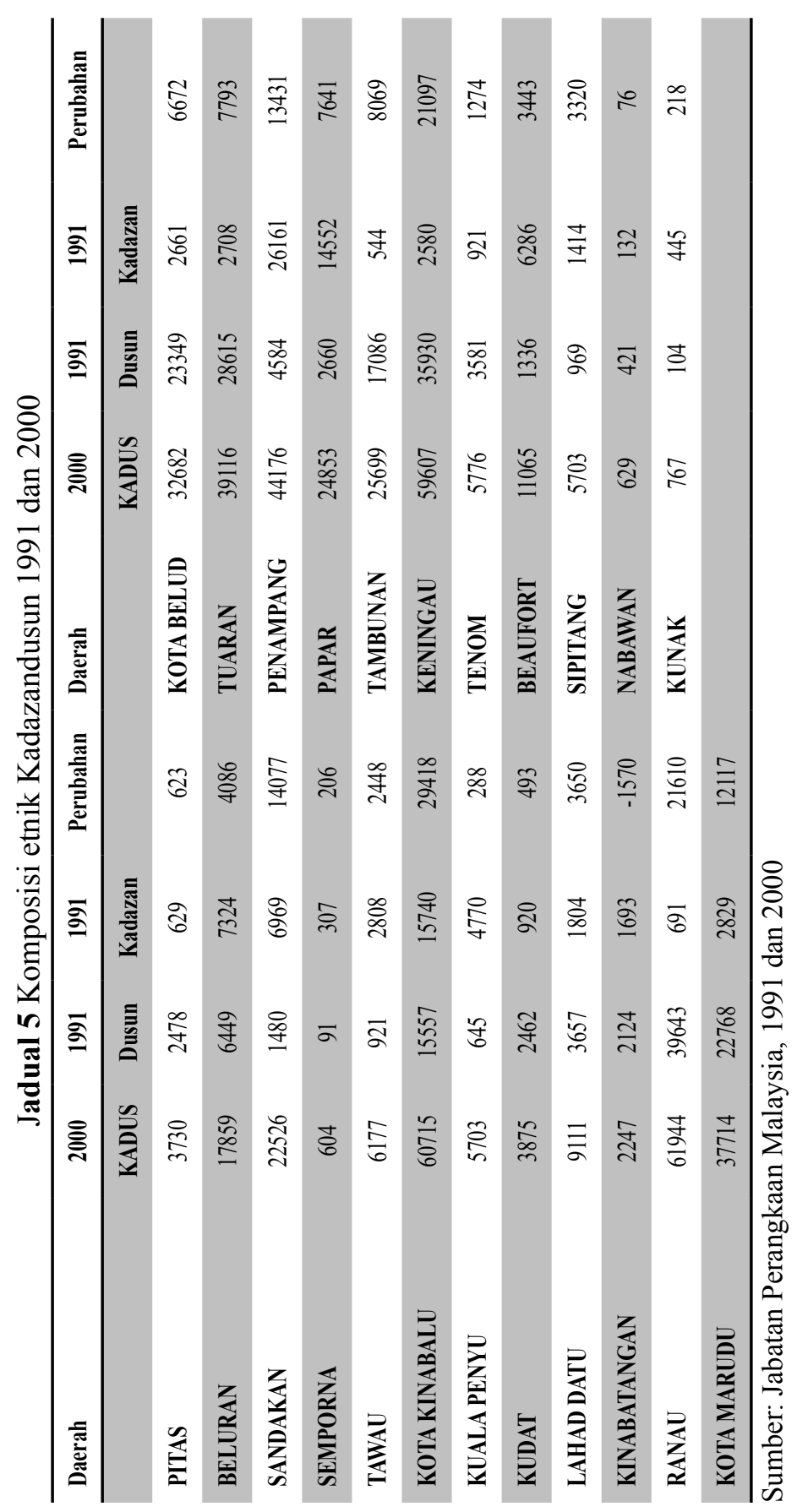




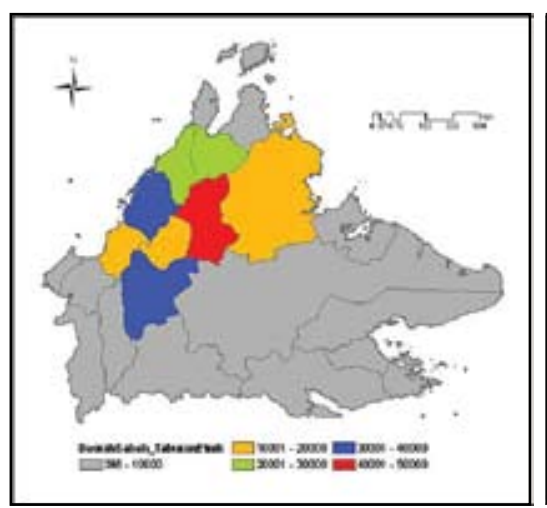

Rajah 6.1 Etnik Kadazandusun 1991

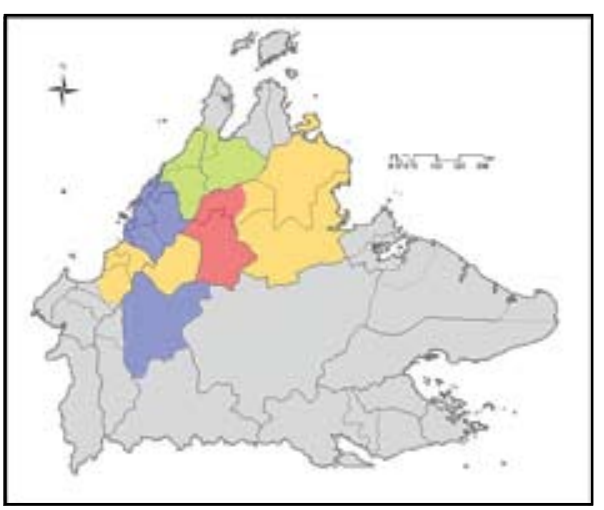

Rajah 6.2 Etnik Kadazandusun 2000

Sumber: Jabatan Perangkaan Malaysia, 1991 \& 2000 dan Jabatan Tanah \& Ukur Sabah

Rajah 6 Taburan etnik Kadazandusun mengikut daerah pentadbiran Sabah

\section{Etnik Kadazandusun dan Persempadanan Pilihan raya 1994}

Dengan merujuk kepada jumlah pengundi yang dikeluarkan oleh pihak SPR dan jumlah penduduk yang dikeluarkan oleh Jabatan Perangkaan Malaysia, didapati kawasan yang majoriti mempunyai daftar pemilih yang mewakili etnik Kadazandusun adalah sebanyak tujuh daerah pentadbiran dan sepuluh kawasan kerusi DUN. Kawasan yang terlibat adalah Ranau (N.25 Ranau dan N.26 Kundasang), Tambunan (N.27 Tambunan), Keningau (N.28 Bingkor), Kota Marudu (N.4 Matunggong dan N.5 Tandek), Kota Belud (N.7 Kadamaian), Tuaran (N.9 Tamparuli dan N.11 Kiulu) serta Penampang (N.16 Moyog). Secara keseluruhannya, kawasan penempatan bagi masyarakat Kadazandusun adalah di sekitar Kota Kinabalu. 


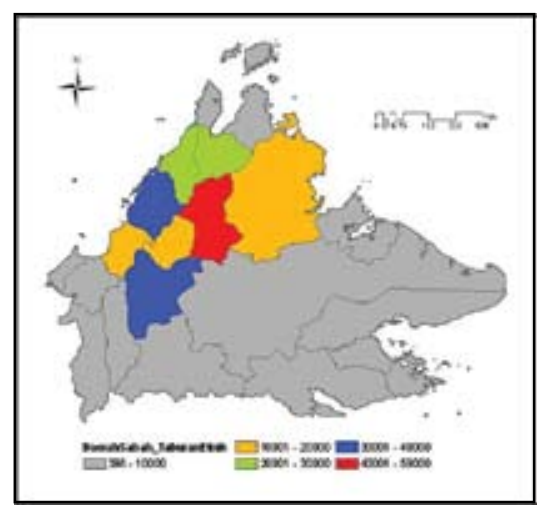

Rajah 7.1 Etnik Kadazandusun 1991

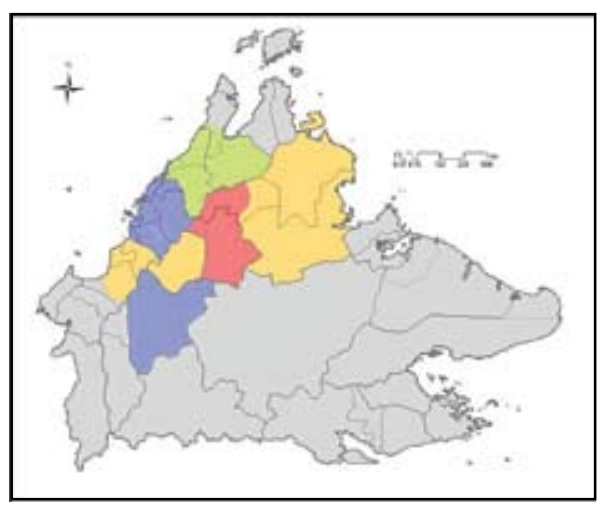

Rajah 7.2 DUN Sabah 1994

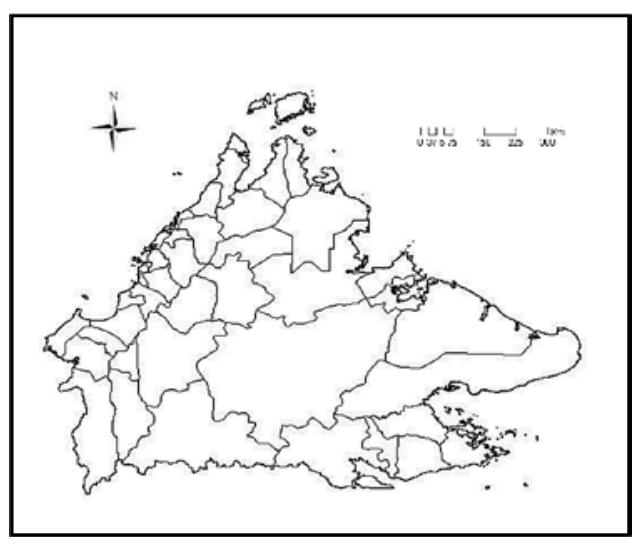

Rajah 7.3 Tindan Lapis (overlay) Etnik Kadazandusun 1991 \& DUN 1994

Sumber: Dipetik dan diubah suai daripada Laporan Perubahan Sempadan Pilihanraya Negeri Sabah Tahun 1993 dan Jabatan Tanah \& Ukur Sabah

Rajah 7 Taburan etnik Kadazandusun 1991 dan persempadanan DUN 1994 


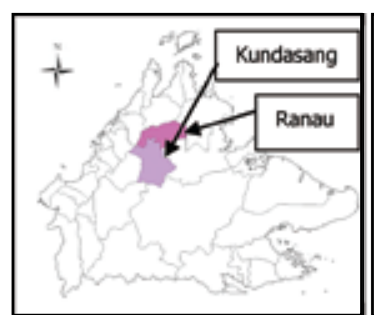

Rajah 8.1 Ranau

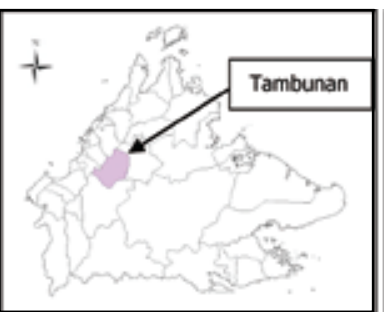

Rajah 8.2 Tambunan

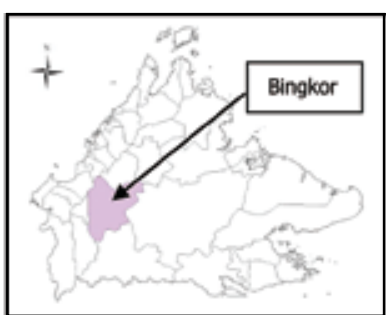

Rajah 8.3 Keningau
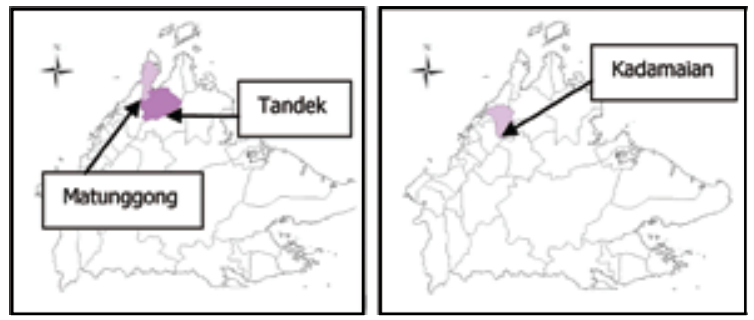

Rajah 8.4 Kota Marudu

Rajah 8.5 Kota Belud

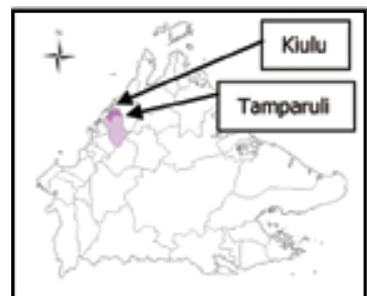

Rajah 8.6 Tuaran

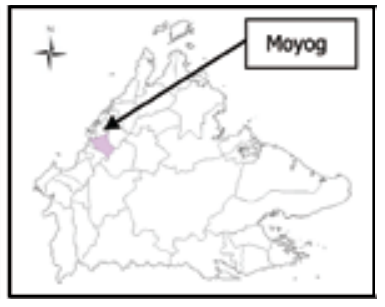

Rajah 8.7 Penampang

Sumber: Dipetik dan diubah suai melalui SPR Malaysia, Jabatan Perangkaan Malaysia, dan Jabatan Tanah \& Ukur Sabah

Rajah 8 Kedudukan DUN etnik Kadazandusun, persempadanan 1994

\section{PERSEMPADANAN PILIHAN RAYA 2004}

Bagi persempadanan yang telah diguna pakai pada pilihan raya tahun 2004, jelas memperlihatkan perubahan jumlah penduduk memberi kesan kepada pertambahan persempadanan. Selain itu, secara tidak langsung 
pertambahan ini akan mengakibatkan perubahan sama ada pertambahan atau pengurangan jumlah penduduk berdasarkan etnik yang ada. Bagi penduduk yang berlatar belakang etnik Kadazandusun memperlihatkan pertambahan jumlah dari angka sebelumnya. Oleh hal yang demikian, tidak mustahil adanya pertambahan dari segi jumlah kerusi DUN bagi etnik ini. Analisis mendapati bahawa terdapat pertambahan yang ketara, iaitu tiga kerusi DUN daripada pertambahan 12 kerusi setelah persempadanan semula dilakukan. Pertambahan kerusi DUN berkenaan sebenarnya hanya melibatkan dua daerah pentadbiran, iaitu Keningau dan Ranau. Bagi daerah pentadbiran yang lain seperti analisis yang dilakukan pada persempadanan tahun 1994 adalah sama. Pertambahan satu kerusi dicatatkan di daerah pentadbiran Ranau iaitu menjadikan tiga kerusi DUN terdiri daripada N.29 Kundasang, N.30 Karanaan dan N.31 Paginatan. Nama parlimen juga turut berubah kepada Ranau yang sebelum ini dikenali sebagai parlimen Kinabalu.

Pertambahan yang paling banyak dicatatkan adalah di Parlimen Keningau iaitu pertambahan sebanyak dua kerusi, iaitu DUN Liawan dan Sook. Biarpun DUN Sook berada di daerah pentadbiran Keningau, pada persempadanan pilihan raya ia diletakkan pada parlimen P.182 Pensiangan. Kerusi DUN yang kekal tanpa perubahan perwakilan nama namun berubah dari segi saiz untuk parlimen Keningau adalah DUN Bingkor. Lima daerah pentadbiran yang turut mewakili etnik Kadzandusun adalah Kota Marudu dengan dua DUN, iaitu Matunggong dan Tandek, Kota Belud diwakili satu kerusi DUN, iaitu Kadamaian, Tuaran masih lagi dengan dua kerusi DUN tanpa sebarang perubahan, iaitu Tamparuli dan Kiulu, Tambunan masih lagi dengan satu DUN, iaitu Tambunan dan akhir sekali adalah Penampang, iaitu bagi DUN Moyog. Perubahan yang ada tidak melibatkan kawasan daerah pentadbiran yang lain tetapi sudah memadai dengan pertambahan kerusi racial gerrymandering apabila terdapat perubahan yang ketara daripada daftar pemilih dan disokong dengan pertambahan jumlah pemilih dari etnik yang sama. 


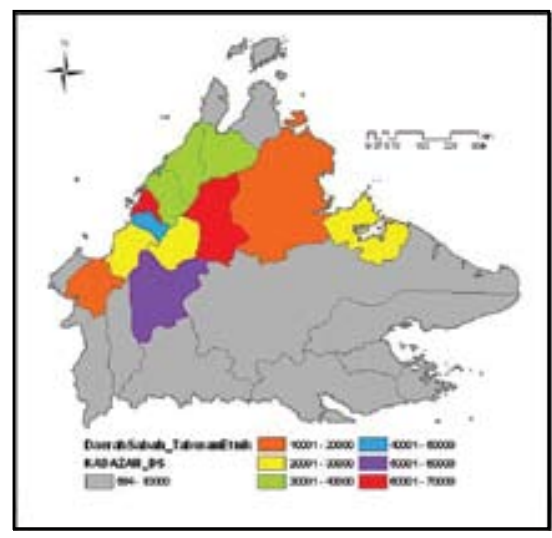

Rajah 9.1 Etnik Kadazandusun 2000

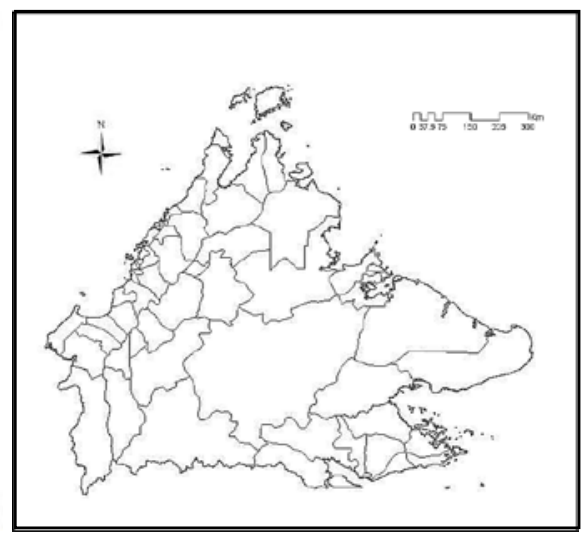

Rajah 9.2 DUN Sabah 2000

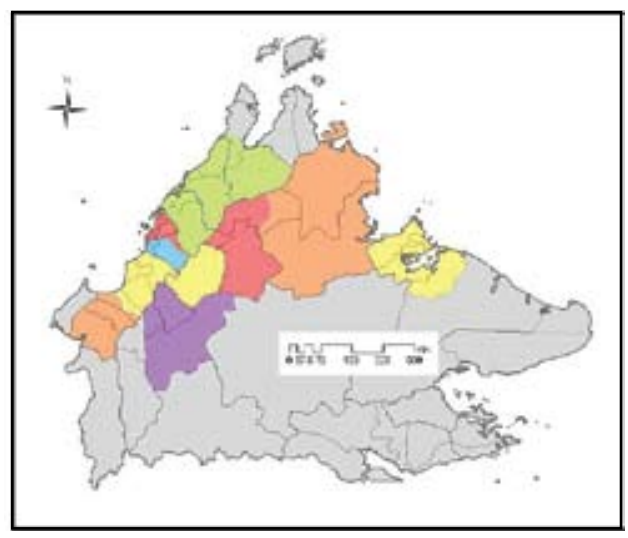

Rajah 9.3 Tindan Lapis (overlay)

Etnik Kadazandusun 2000 \& DUN 2004

Sumber: Dipetik dan diubah suai daripada Laporan Perubahan Sempadan Pilihanraya Negeri Sabah Tahun 2003 dan Jabatan Tanah \& Ukur Sabah

Rajah 9 Taburan etnik Kadazandusun 2000 dan persempadanan DUN 2004 


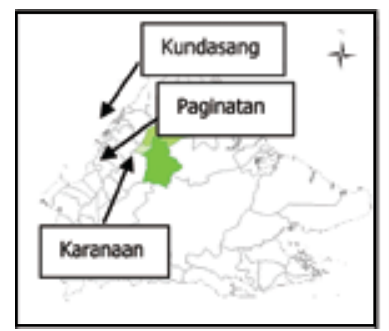

Rajah 10.1 Ranau

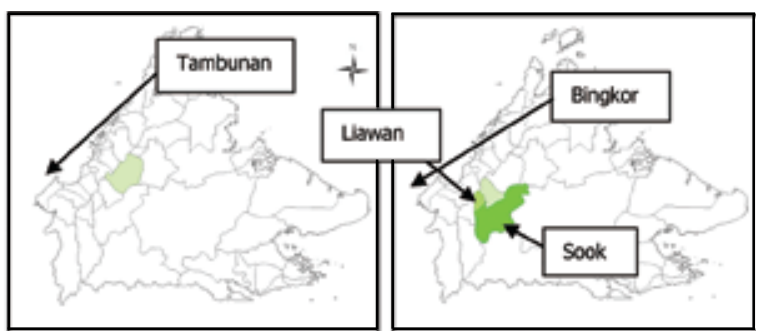

Rajah 10.2 Tambunan

Rajah 10.3 Keningau
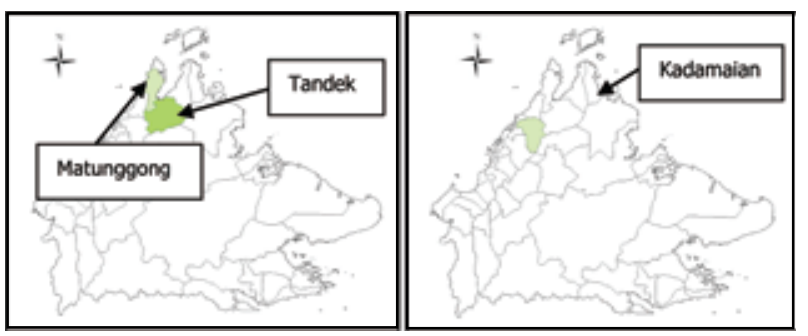

Rajah 10.4 Kota Marudu Rajah 10.5 Kota Belud
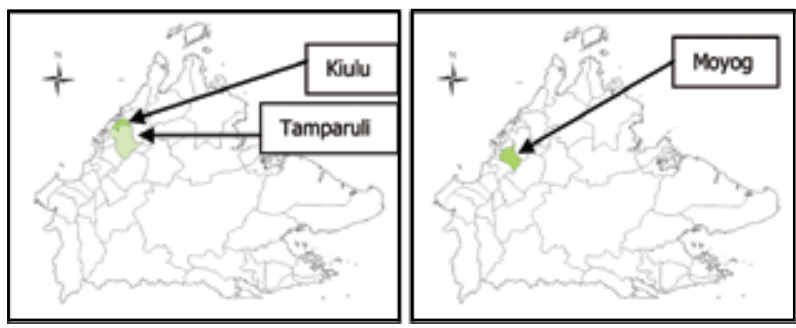

Rajah 10.6 Tuaran

Rajah 10.7 Penampang

Sumber: Dipetik dan diubah suai daripada Laporan Perubahan Sempadan Pilihan raya Negeri Sabah Tahun 2003 dan Jabatan Tanah \& Ukur Sabah

Rajah 10 Kedudukan DUN etnik Kadazandusun, persempadanan 2004 


\section{PERBANDINGAN PEMBAHAGIAN PERSEMPADANAN PILIHAN RAYA 1994 DAN 2004 BAGI ETNIK KADAZANDUSUN}

Secara keseluruhannya, terdapat pertambahan tiga kerusi bagi etnik Kadazandusun akibat perubahan persempadanan pilihan raya, menjadikan jumlah keseluruhan yang dicatatkan bagi etnik Kadazandusun adalah 13 kerusi pada tahun 2004 dan tahun sebelum persempadanan adalah sebanyak sepuluh kerusi DUN sahaja. Pertambahan tiga kerusi DUN berkenaan kesemuanya terletak di kawasan pedalaman Sabah, iaitu dua di Keningau dan satu di Ranau. Bagi kawasan lain jumlah kerusi adalah sama seperti persempadanan tahun 1994 biarpun terdapat perubahan persempadanan yang dilakukan oleh SPR, Malaysia. Pantai barat negeri Sabah masih kekal dengan jumlah yang sama, iaitu memiliki empat kerusi DUN dengan agihan dua DUN di Tuaran dan masing-masing satu DUN di Kota Belud dan Penampang. Pedalaman Sabah pula adalah 'lubuk emas' bagi DUN etnik Kadazandusun dengan sembilan kerusi keseluruhannya, iaitu tiga kerusi di Ranau dan Keningau, dua kerusi DUN di Kota Marudu satu kerusi DUN di Tambunan. Bagi kawasan pantai timur seperti yang telah dinyatakan sebelum ini tidak terdapat kerusi DUN bagi etnik Kadazandusun. Keseluruhan perubahan persempadanan boleh dilihat melalui Rajah 11.3.

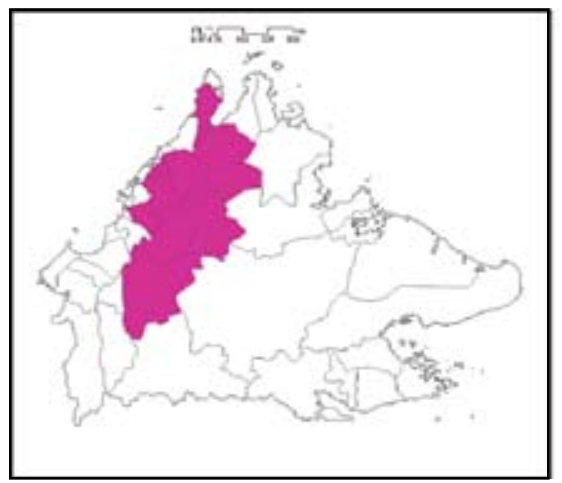

Rajah 11.1 Persempadanan 1991

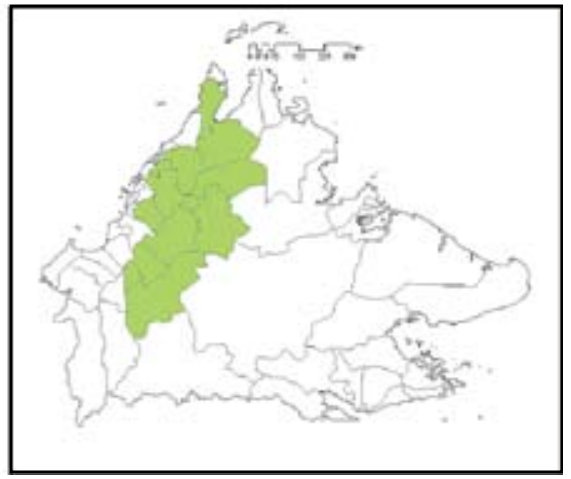

Rajah 11.2 Persempadanan 2004 


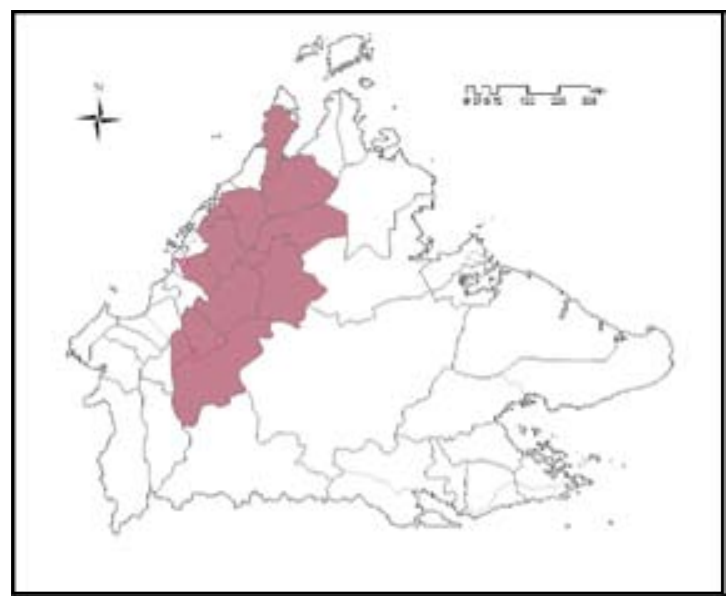

Rajah 11.3 Tindan Lapis Persempadanan 1994 dan 2004

Sumber: Dipetik dan diubah suai melalui SPR Malaysia, Jabatan Perangkaan Malaysia dan Jabatan Tanah \& Ukur Sabah

Rajah 11 Taburan peletakan ruangan DUN bagi etnik Kadazandusun

\section{KESIMPULAN}

Secara keseluruhannya, indikator etnik menjadi salah satu kriteria penting dalam menentukan persempadanan pilihan raya. Namun, tidak dinyatakan secara jelas dalam perubahan persempadanan pilihan raya yang biasanya akan diwakili oleh jumlah penduduk keseluruhan. Penggunaan data daripada indikator etnik berkenaan jelas memberi impak kepada penentuan persempadanan ruangan politik, terutamanya DUN di Sabah dan secara tidak langsung memperlihatkan penerapan konsep racial gerrymandering ada diaplikasikan di Sabah. Jika dianalisis secara terperinci, perubahan ruangan yang ada juga melibatkan perubahan nama kerusi kawasan Parlimen dan jelas menunjukkan bahawa setiap Parlimen yang ada telah menggunakan nama daerah pentadbiran itu sendiri untuk mewakili kerusi berkenaan. Sebelum perubahan persempadanan 2003, semua kerusi parlimen yang diwakili oleh etnik Kadazandusun diwakili berdasarkan nama daerah pentadbiran kecuali 
Ranau yang dikenali sebagi parlimen Kinabalu, akan tetapi pada pilihan raya 2004, nama Kinabalu telah digantikan dengan Ranau.

Dalam perubahan berkaitan dengan pertambahan ruangan baharu pula memperlihatkan bahawa satu daerah pentadbiran boleh dibahagikan kepada beberapa buah kerusi DUN yang tidak semestinya akan mewakili Parlimen yang merujuk kepada sesuatu daerah pentadbiran. Sebagai contoh, perubahan yang berlaku pada DUN Sook yang terletak di daerah pentadbiran Keningau dan pada pilihan raya 1994 diletakkan di bawah Parlimen Keningau dengan satu DUN sahaja, iaitu Bingkor. Pertambahan DUN Sook ini diletakkan di bawah parlimen Pensiangan setelah persempadanan 2003 dan diguna pakai pada pilihan raya 2004. Hal ini jelas membuktikan bahawa konsep peningkatan dan kemajuan kawasan dalam konteks memberi kesamarataan, pengagihan kemudahan kepada rakyat dalam kriteria perubahan persempadanan telah diambil kira dalam perubahan persempadanan yang ada.

\section{RUJUKAN}

Agnew, J. (1987). Place \& politics. London: Allen \& Unwin Publication.

Andaya, B.W. \& Andaya L.Y. (2001). A history of Malaysia. Basingstoke: Palgrave Press.

Blacksell, M. (2006). Political Geography. London:Routledge Publisher.

Boots, B. (2000). Geographic representation in spatial analysis. London: Routledge Publisher.

Clarks, W. \& Housing, P.L. (1986). Statistical methods for Geographers ( $3^{r d}$ ed.). Canada: John Wiley \& Sons Inc

Forest, B. (2007). Spatial demography special features: The changing demographic, legal and technological context of political representative. http://pnas.org

Glassner, M.I. (1995). Political geography (2 ${ }^{\text {nd }} e d$.). New York:John Wiley \& Sons Inc.

Haring, L.L. et al. (1992). Introduction to scientifics geography research. Dubuque: WM. C., Brown.

Hooker, V.M. (2000). A short history of Malaysia: Linking east \& west. New South Wales: Allen \& Unwin Publisher. 
Joisin Romut. (2004). The influence of emotional intelligence on leadership styles among the Kadazandusun community. Kota Kinabalu: Universiti Malaysia Sabah.

Kasperson, R.E. (1973). Frontiers of political geography. New Jersey: PrenticeHall Press.

Laporan Perubahan Persempadanan Negeri Sabah. (1994). Suruhanjaya Pilihanraya Malaysia.

Laporan Rancangan Malaysia Kelapan: Jabatan Perangkaan Malaysia.

Laporan Pilihanraya Umum Dewan Undangan Negeri Sabah, 1994.

Laporan Pilihanraya Umum Dewan Undangan Negeri Sabah, 2004.

Laporan Perubahan Persempadanan Negeri Sabah, 2004. Suruhanjaya Pilihanraya Malaysia.

Miller, H.V. (2000). Using GIS to promote spatial analysis. New York: Charles E. Merrills Publishing.

Mohamad Ariff bin Dato' Haji Othman. (1988). Tuntutan Filipina terhadap Sabah: Implikasi dari segi sejarah, undang-undang dan politik. Kuala Lumpur: Kementerian Pendidikan Malaysia.

Norris, R.E \& Harring, L.L. (1980). Political geography. New York: Charles E. Merrills Publishing.

O’Tuathail, G. \& Dalby, P. (1998). Critical geopolitics: The politic of writing global space. Minneapolis: University of Minnesota Press.

Paasi, A. (2002). The changing discourses on political boundaries: Mapping the background, contexts and contents. England: Ashgate Publication.

Pendley, W.P. (2007). Racial gerrymandering in “The equality state." http//www. townhall.com/WillianPerryPendley .

Taburan Penduduk Sabah Tahun 1991. Jabatan Perangkaan Malaysia.

Taburan Penduduk Sabah Tahun 2000. Jabatan Perangkaan Malaysia. 
